\section{Propagation of Ultrasonic Waves in Liquids}

We had observed ${ }^{1}$ that the heat generated by ultrasonic waves in carbon disulphide and in other liquids, such as toluene and xylene, is not in conformity with their widely divergent absorption coefficients as measured by other (acoustic) methods. To clarify the point further, we have made a set of messurements with the type of apparatus described in ref. 1 .

Working at about $32^{\circ} \mathrm{C}$, it was observed with a particular apparatus that the total power generated by a vibrating quartz crystal, placed inside a container with kerosene oil or xylene, was 9 watts, as obtained from the steady temperature difference between the container and the circulating water outside. Energies were also messured in a trapvessel, placed at a definite distance from the quartz; on both sides of it when the quartz was in the middle of the container, and on one side only when the quartz was near the end. It was observed that the energy propagated forward from the quartz placed near one end was 25 per cent higher than from the other position, where it was propagated equally on both sides. The energy propagated forward was thus found to be $5 \cdot 6$ watts only.

Messurements were taken with trap-vessels of different sizes, placed at different distances from the quartz, which was near the end of the container. The liquids outside and inside the trap vessels were varied. It will be seen from Table 1 that $\alpha / f^{2}$, obtained from the variation of power with distance, drops from a comparatively large value near the quartz to a value of approximately the same order as that obtained by other methods.

A direct measure of the energy incident on a trapvessel, passing through kerosene oil and out on the farther side, was obtained by placing the trap in a closely fitting glass container, $5 \mathrm{~cm}$. from the quartz. The container was thus virtually partitioned into three thermostatic chambers, except for the communicating mica windows. It was cooled by water circulating outside. The power on the farther side of the trap-vessel was measured from the temperature difference between it and the circulating water. This is a measure of the vibrational and turbulent energy as well as of the heat passing out of the trap, having regard to the temperatures on the two sides. We obtained a value of 4.5 watts, incident on the trapvessel transmitted through the windows, irrespective of the liquid inside.

The variation of the measured power with distance has already been noted. It shows that when the incident energy at $5 \mathrm{~cm}$. from the quartz is 4.5 watts, the power output at the quartz is not less than $5 \cdot 6$ watts. It accounts for the energy that was found to be propagated from the quartz, and it appears that the mica windows do not reflect any detectable energy.

The power measured in the different vessels, placed at $5 \mathrm{~cm}$. from the quartz, gives, having regard to the incident energy, a very high absorption coefficient for liquids known to have low absorbing power.

The coefficients, in the form $\alpha / f^{2}$, so derived are shown in Table 1 (column 7).

The higher absorption of ultrasonic waves near the source as determined by energy variation with displacement is to be associated with the inharmonic character of the waves observed by Hubbard ${ }^{2}$. Moreover, the excessively high absorption in the
Table 1

\begin{tabular}{|c|c|c|c|c|c|c|}
\hline $\begin{array}{l}\text { Liquidid } \\
\text { (a) outside } \\
\text { (b) in trap }\end{array}$ & $\begin{array}{l}\text { Dist- } \\
\text { ance } \\
\text { from } \\
\text { quartz } \\
\text { (cm.) }\end{array}$ & $\begin{array}{c}\text { Trap } \\
\text { vessel } \\
\text { size } \\
(\mathrm{cm} .)\end{array}$ & $\begin{array}{c}\text { Power } \\
\text { in } \\
\text { traps } \\
\text { (watts) }\end{array}$ & $\begin{array}{c}\text { Inci- } \\
\text { dent } \\
\text { power } \\
\text { at } \\
5 \text { cm. } \\
\text { (watts) }\end{array}$ & $\begin{array}{l}\frac{\alpha}{f^{2}} \times 10^{17} \\
\text { from dis- } \\
\text { placement, } \\
\underset{\substack{\text { liquid } \\
(a)}}{ }\end{array}$ & $\mid \begin{array}{c}\frac{\alpha}{f^{2}} \times 10^{17} \\
\text { from } \\
\text { incident } \\
\text { energy, } \\
\text { liquid } \\
\text { (b) }\end{array}$ \\
\hline $\begin{array}{l}\text { (a) Kerosene } \\
\text { (b) Kerosene }\end{array}$ & $\begin{array}{r}2 \\
5 \\
10 \\
15\end{array}$ & $\left\{\begin{array}{r}1 \\
1 \\
5 \\
15 \\
1 \\
1\end{array}\right.$ & $\begin{array}{l}1 \cdot 5 \\
1 \cdot 2 \\
2 \cdot 0 \\
3 \cdot 0 \\
1 \cdot 0 \\
0 \cdot 85\end{array}$ & $4 \cdot 5$ & $\begin{array}{l}408 \\
200 \\
180\end{array}$ & $\left\{\begin{array}{c}1,722 \\
666 \\
400\end{array}\right.$ \\
\hline $\begin{array}{l}\text { (a) Xylene } \\
\text { (b) Xylene }\end{array}$ & $\begin{array}{r}2 \\
5 \\
10 \\
15\end{array}$ & $\left\{\begin{array}{r}1 \\
1 \\
5 \\
15 \\
1 \\
1\end{array}\right.$ & $\left\{\begin{array}{l}1 \cdot 4 \\
1 \cdot 02 \\
1 \cdot 9 \\
2 \cdot 3 \\
0 \cdot 81 \\
0 \cdot 70\end{array}\right.$ & $4 \cdot 5$ & $\begin{array}{l}583 \\
255 \\
166\end{array}$ & $\left\{\begin{array}{r}1,444 \\
600 \\
270\end{array}\right.$ \\
\hline $\begin{array}{l}\text { (a) Kerosene } \\
\text { (b) Carbon } \\
\text { disulphide }\end{array}$ & 5 & $\left\{\begin{array}{r}1 \\
5 \\
15\end{array}\right.$ & $\left\{\begin{array}{l}2 \cdot 0 \\
2 \cdot 3 \\
2 \cdot 4\end{array}\right.$ & $4 \cdot 5$ & & $\left\{\begin{array}{r}3,330 \\
800 \\
325\end{array}\right.$ \\
\hline
\end{tabular}

1-cm. trap-vessel, for low-absorption type liquids, was not caused by reflexion from the mice. It has also been confirmed that diffraction by the aperture does not account for this effect. The observations appear capable of explanation on the basis of a phase retardation of the components of the inharmonic wave-form, introduced by the first mica window. They become progressively out of step and are thus prevented from being fully transmitted by the second mica window. Even in unobstructed liquids, this mechanism appears to operate to a small extent and to account for the larger loss of energy at smaller distances. It supports the conclusion that the excessive absorption of ultrasonic waves noted in carbon disulphide and benzene (and possibly also the discrepancy from the Stokes absorption coefficient in other liquids) is due to a mechanism which produces more or less effectively a confusion in phase relationship during propagation, in the same way that the mice window does for low-absorption liquids such as xylene. It thus appears that wave trains in liquids can lose energy, as if by scattering, in a manner similar to that noted by Richardson ${ }^{3}$ in the case of gases.

\section{A. K. Dutta}

K. SAMaI

Ravenshaw College, Cuttack.

${ }^{1}$ Dutta, A. K., and Samal, K., Nature, 174, 976 (1954) ; 179, 95 (1957) Hubbard, J. C., Fitzpatrick, P. A., Kankovsky, B. T., and Thaler, W. J., Phys. Rev., 74, 107 (1948)

${ }^{3}$ Richardson, E. G., Proc. Roy. Soc., A, 146, 56 (1934).

\section{Protection of Fotuses against Radiation Injury}

THe protection against a lethal dose of radiation, conferred on mice by grafts of hrmopoietic tissue, is being attributed to repopulation of homologous tissues of the host by cells from the graft'. This does not, however, exclude the possibility that such grafts might also be supplying a subcellular factor able to contribute to the recovery of the host.

To test the latter possibility, female mice of strain $A$ were given, on the fourteenth day of pregnancy, 8 dose of X-rays amounting to $275 \mathrm{r}$. Immediately following this, and always under ether anæesthesia, they were splenectomized. One group was treated no further, while each animal of a second group was 